Tao Ding*, Zhenni Guo, Chengxi Ying

\title{
Contamination Status and Potential Ecological Risks of Heavy Metal in Sediments from the Qiantang River
}

\begin{abstract}
Heavy metal sediment contamination can significantly damage the ecological water environment. In this paper, we collected superficial sediment samples at 26 different sampling sites, and then tested and evaluated their contamination status and potential ecological risks. The sediment analysis results showed that $\mathrm{Cu}$, $\mathrm{Zn}$, As, $\mathrm{Cd}$, and $\mathrm{Pb}$ contents were excessive compared with local soil background levels. There is a low or moderate potential ecological risk level from heavy metal pollution in sediments in the study area; $\mathrm{Cd}$ is the element with the potential to cause the most ecological damage.
\end{abstract}

Keywords: component, heavy metal, ecological risk, river sediment, Qiantang River.

\section{Introduction}

With industrial development and population growth, environmental pollution caused by industrial wastewater and domestic sewage has become increasingly serious. Urban river pollution has gradually intensified. River sediment is an important component of the water ecological environment. On the one hand, sediments can absorb pollutants in water and relieve water pollution. However, sediment can also release pollutants back into the water upon external environmental changes and thus cause secondary water pollution [1,2]. Sediment is the main living place and food source for benthos. Pollutants in sediments could access terrestrial biota and human bodies through biological concentration and the food chain [3-5].

Urbanization, industrialization, and intensive agricultural development have increased heavy metal contents in river sediments [6]. Because of their toxicity, durability, and non-degradability [7], heavy metals have become key pollutants that significantly influence sediment quality $[8,9]$ and cause sediment to be a secondary pollution source. Therefore, it is necessary to detect heavy metals in river sediments to evaluate heavy metal pollution levels and corresponding potential risks [10-15]. The results from this study will help develop strategies for river pollution control and the ecological dredging of rivers in the Zhejiang province, China, and will also provide reference information for similar areas.

\footnotetext{
*Corresponding author: Tao Ding, College of Quality \& Safety Engineering, China Jiliang University, Hangzhou, China, E-mail: dingtaohz@163.com

Zhenni Guo, Chengxi Ying, College of Quality \& Safety Engineering, China Jiliang University, Hangzhou, China

This study was supported by Natural Science Foundation of Zhejiang Province (No. LY13E090005)
} 


\section{Materials and methods}

\subsection{Description of Study Area}

In this paper, sampling sites were mainly in Hangzhou and Jiaxing along the Qiantang River. Table 1 shows the spatial distribution of sampling sites.

Table 1: Distribution of Sediment Sampling Sites

\begin{tabular}{|c|c|c|}
\hline \multirow{2}{*}{$\begin{array}{l}\text { Sample } \\
\text { Site }\end{array}$} & \multicolumn{2}{|c|}{ Longitude and latitude } \\
\hline & Longitude & latitude \\
\hline 1 & $30^{\circ} 39^{\prime} 15^{\prime \prime}$ & $120^{\circ} 31^{\prime} 49^{\prime \prime}$ \\
\hline 2 & $30^{\circ} 14^{\prime} 49^{\prime \prime}$ & $120^{\circ} 07^{\prime} 40^{\prime \prime}$ \\
\hline 3 & $30^{\circ} 01^{\prime} 41^{\prime \prime}$ & $120^{\circ} 01^{\prime} 03^{\prime \prime}$ \\
\hline 4 & $30^{\circ} 01^{\prime} 39^{\prime \prime}$ & $120^{\circ} 00^{\prime} 28^{\prime \prime}$ \\
\hline 5 & $30^{\circ} 14^{\prime} 50^{\prime \prime}$ & $120^{\circ} 07^{\prime} 37^{\prime \prime}$ \\
\hline 6 & $30^{\circ} 06^{\prime} 16^{\prime \prime}$ & $120^{\circ} 12^{\prime} 58^{\prime \prime}$ \\
\hline 7 & $30^{\circ} 06^{\prime} 02^{\prime \prime}$ & $120^{\circ} 12^{\prime} 49^{\prime \prime}$ \\
\hline 8 & $30^{\circ} 15^{\prime} 33^{\prime \prime}$ & $120^{\circ} 03^{\prime} 44^{\prime \prime}$ \\
\hline 9 & $30^{\circ} 39^{\prime} 15^{\prime \prime}$ & $120^{\circ} 31^{\prime} 49^{\prime \prime}$ \\
\hline 10 & $30^{\circ} 04^{\prime} 36^{\prime \prime}$ & $120^{\circ} 12^{\prime} 03^{\prime \prime}$ \\
\hline 11 & $30^{\circ} 07^{\prime} 49^{\prime \prime}$ & $120^{\circ} 12^{\prime} 44^{\prime \prime}$ \\
\hline 12 & $30^{\circ} 19^{\prime} 27^{\prime \prime}$ & $120^{\circ} 08^{\prime} 57^{\prime \prime}$ \\
\hline 13 & $30^{\circ} 09^{\prime} 09^{\prime \prime}$ & $120^{\circ} 13^{\prime} 52^{\prime \prime}$ \\
\hline 14 & $30^{\circ} 13^{\prime} 48^{\prime \prime}$ & $120^{\circ} 08^{\prime} 11^{\prime \prime}$ \\
\hline 15 & $29^{\circ} 39^{\prime} 02^{\prime \prime}$ & $119^{\circ} 04^{\prime} 42^{\prime \prime}$ \\
\hline 16 & $29^{\circ} 27^{\prime} 52^{\prime \prime}$ & $119^{\circ} 15^{\prime} 28^{\prime \prime}$ \\
\hline 17 & $30^{\circ} 06^{\prime} 43^{\prime \prime}$ & $120^{\circ} 11^{\prime} 13^{\prime \prime}$ \\
\hline 18 & $30^{\circ} 03^{\prime} 23^{\prime \prime}$ & $119^{\circ} 57^{\prime} 38^{\prime \prime}$ \\
\hline 19 & $30^{\circ} 03^{\prime} 13^{\prime \prime}$ & $119^{\circ} 56^{\prime} 52^{\prime \prime}$ \\
\hline 20 & $30^{\circ} 44^{\prime} 38^{\prime \prime}$ & $121^{\circ} 01^{\prime} 49^{\prime \prime}$ \\
\hline 21 & $30^{\circ} 42^{\prime} 07^{\prime \prime}$ & $121^{\circ} 16^{\prime} 09^{\prime \prime}$ \\
\hline 22 & $30^{\circ} 04^{\prime} 17^{\prime \prime}$ & $120^{\circ} 11^{\prime} 07^{\prime \prime}$ \\
\hline 23 & $30^{\circ} 39^{\prime} 58^{\prime \prime}$ & $120^{\circ} 30^{\prime} 32^{\prime \prime}$ \\
\hline 24 & $30^{\circ} 06^{\prime} 24^{\prime \prime}$ & $120^{\circ} 14^{\prime} 07^{\prime \prime}$ \\
\hline 25 & $30^{\circ} 16^{\prime} 39^{\prime \prime}$ & $120^{\circ} 10^{\prime} 54^{\prime \prime}$ \\
\hline 26 & $29^{\circ} 59^{\prime} 22^{\prime \prime}$ & $119^{\circ} 41^{\prime} 8^{\prime \prime}$ \\
\hline
\end{tabular}

\subsection{Sample Collection and Processing}

Superficial sediment samples were collected with piston samplers (Fig. 1) and kept in sealed, labelled bags. The samples were naturally air-dried in a cool, ventilated laboratory. Impurities such as gravel and animal and plant residue were removed. Later, the samples were tiled on a piece of solid fiberboard and pressed with a glass 
rod. Samples were sifted by a 20-mesh sieve to remove oversized substances. Sifted samples were divided through a quartering sample method, and the samples were ground by an agate mortar until they could be sifted through a 100-mesh sieve. The processed samples were sealed for later tests.

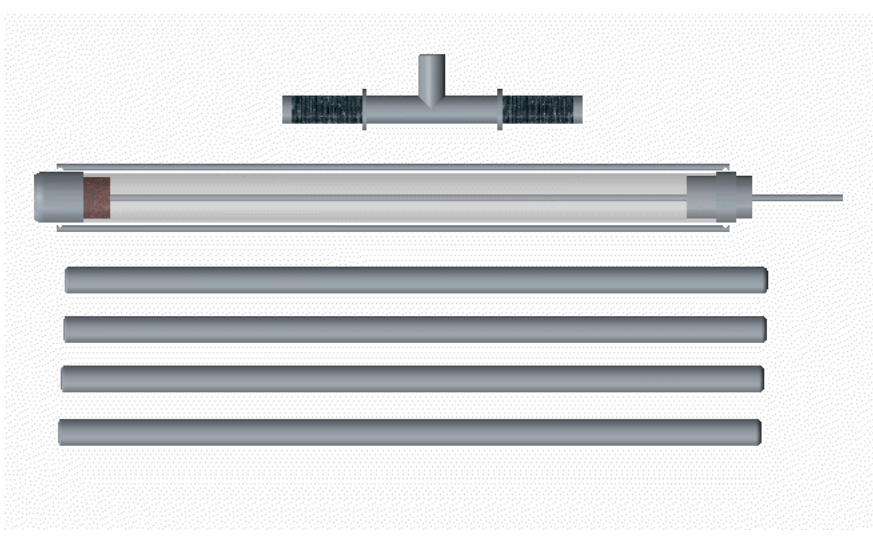

Figure 1: Sample analytical methods

\subsection{Assessment of Potential Ecological Risk}

The sample analysis process had 2 stages: sample pretreatment and heavy metal detection. The sample pretreatment steps were as follows: first, a weighed, dried sediment sample $(0.4 \mathrm{~g} \pm 0.0002 \mathrm{~g})$ was put into a clean PTFE crucible, and $6 \mathrm{~mL}$ hydrochloric acid ( $\mathrm{HCl}[36 \%])$ was added on a hot plate at $100^{\circ} \mathrm{C}$ until only $2 \mathrm{~mL}$ of solution remained. When cooled, a combination of a certain volume of nitric acid $\left(\mathrm{HNO}_{3}[69 \%]\right)$, hydrofluoric acid ( $\left.\mathrm{HF}[48 \%]\right)$, and $3 \mathrm{~mL}$ perchloric acid $\left(\mathrm{HClO}_{4}[70 \%]\right)$ was added on a hot plate between 120 and $150^{\circ} \mathrm{C}$ until it was nearly dry. The digested sediment solution was diluted with deionized water and filtered quantitatively into a $50 \mathrm{~mL}$ volumetric flask. The heavy metal contents ( $\mathrm{Ni}, \mathrm{Cu}, \mathrm{Zn}, \mathrm{As}, \mathrm{Cd}$, and $\mathrm{Pb}$ ) in the sediment samples after pretreatment were detected by ICP-MS.

\subsection{Assessment of Potential Ecological Risk}

Hakanson developed the Potential Ecological Risk Index [16] to evaluate damage to the environment from heavy metals in the sediment, and to assess heavy metal pollution. It integrates the concentrations of heavy metals, their toxic responses and ecological factors, and shows the combined effect of many types of heavy metals. The potential risk index can be calculated as follows: 


$$
\begin{aligned}
& C_{f}^{i}=C_{h}^{i} / C_{n}^{i} \\
& E_{r}^{i}=T_{r}^{i} \times C_{f}^{i} \\
& \mathbb{R}=\sum_{i=1}^{n} E_{r}^{i}=\sum_{i=1}^{n} T_{r}^{i} \times C_{f}^{i}
\end{aligned}
$$

where $C_{f}^{i}$ is the contamination coefficient for a certain heavy metal, and $C_{h}^{i}$ is the measured value of the heavy metal. $\mathrm{C}_{\mathrm{n}}^{\mathrm{i}}$ is a reference value for heavy metals. $\mathrm{E}_{\mathrm{r}}^{\mathrm{i}}$ is the potential ecological risk index for heavy metal pollution from one metal. $\mathrm{T}_{\mathrm{r}}^{\mathrm{i}}$ is the toxic response factor of heavy metals that indicates the hazards of heavy metals on human and aquatic ecosystems, and reflects the levels of heavy metal toxicity and ecological sensitivity to heavy metal pollution. RI represents the potential ecological risk index of multiple heavy metals.

In this study, we adopted the environmental background levels of heavy metals from Wang et al. [17] to evaluate the pollution level. Table 2 lists the local background value and the toxic response factor of heavy metals in sediments.

Table 2: The Local Background Value and the Toxic Response Factor of Heavy Metals in Sediments $[16,17]$.

\begin{tabular}{lllllll}
\hline Metals & $\mathbf{N i}$ & $\mathrm{Cu}$ & $\mathbf{Z n}$ & $\mathbf{A s}$ & $\mathbf{C d}$ & $\mathbf{P b}$ \\
\hline$C_{n}^{i}$ & 41.10 & 40.80 & 110.00 & 10.00 & 0.21 & 38.20 \\
$T_{r}^{i}$ & 1 & 10 & 5 & 5 & 30 & 5 \\
\hline
\end{tabular}

\section{Results and discussion}

\subsection{Concentrations and Distribution of Heavy Metals in Sediments}

Based on Equation (1), heavy metal concentrations in sediment surfaces $\left(\mathrm{C}_{\mathrm{h}}^{\mathrm{i}}\right)$ should be measured. Table 3 presents the concentrations of $\mathrm{Cu}, \mathrm{Zn}, \mathrm{Pb}, \mathrm{Cd}, \mathrm{AS}$, and $\mathrm{Ni}$ in surface sediments. Ni concentrations were lower than the background levels at most sampling sites (except No.18). The Fig. 2 for $\mathrm{Cu}$ was also lower than the background levels at most sampling sites (except across 4 sites), but was nearly 10 times higher than the background level at site No.17. On the other hand, the concentrations of other metals ( $\mathrm{Pb}, \mathrm{Cd}, \mathrm{As}$, and $\mathrm{Zn}$ ) were higher than the background levels at more than half of sampling sites, especially for $\mathrm{Cd}$. The standard exceedance rates of $\mathrm{Cu}, \mathrm{Zn}$, $\mathrm{As}, \mathrm{Cd}$, and $\mathrm{Pb}$ were 4\%, 15\%, 27\%, 50\%, 81\%, and 58\% respectively. The maximum concentrations of $\mathrm{Cu}, \mathrm{Zn}, \mathrm{As}, \mathrm{Cd}$, and $\mathrm{Pb}$ were 9.90, 3.86, 2.23, 15.74, and 3.43 times greater than the background values, respectively, while the average concentrations 
of $\mathrm{Cu}, \mathrm{Zn}, \mathrm{As}, \mathrm{Cd}$, and $\mathrm{Pb}$ were 1.09, 1.28, 1.07, 3.62, and 1.17 times greater than the background values, respectively. Of all the metals, pollution from $\mathrm{Cd}$ is the most serious. The pollution levels decrease in the order $\mathrm{Cd}>\mathrm{Zn}>\mathrm{Pb}>\mathrm{Cu}>\mathrm{As}$.

Table 3: The Concentrations ( $\mathrm{mg} \mathrm{kg}^{-1}$ ) of Heavy Metals in Surface Sediments.

\begin{tabular}{|c|c|c|c|c|c|c|}
\hline Sampling site & $\mathrm{Ni}$ & $\mathrm{Cu}$ & $\mathrm{Zn}$ & As & Cd & $\mathrm{Pb}$ \\
\hline 1 & 34.02 & 23.20 & 62.71 & 0.01 & 0.27 & 32.14 \\
\hline 2 & 37.72 & 34.52 & 151.46 & 10.30 & 0.91 & 40.12 \\
\hline 3 & 20.77 & 29.70 & 54.21 & 9.79 & 1.12 & 81.80 \\
\hline 4 & 22.66 & 34.85 & 105.37 & 9.55 & 1.15 & 87.17 \\
\hline 5 & 17.61 & 51.61 & 861.55 & 10.03 & 0.75 & 48.13 \\
\hline 6 & 26.84 & 35.32 & 77.72 & 10.51 & 1.46 & 64.46 \\
\hline 7 & 24.02 & 89.31 & 256.49 & 10.66 & 1.42 & 50.79 \\
\hline 8 & 34.04 & 24.49 & 85.59 & 14.59 & 0.28 & 29.83 \\
\hline 9 & 25.48 & 24.67 & 118.72 & 17.22 & 0.48 & 35.29 \\
\hline 10 & 20.90 & 19.58 & 65.46 & 8.42 & 0.37 & 28.22 \\
\hline 11 & 21.71 & 26.00 & 80.93 & 13.31 & 1.21 & 60.20 \\
\hline 12 & 32.04 & 25.72 & 56.95 & 8.81 & 0.13 & 28.36 \\
\hline 13 & 31.96 & 33.83 & 107.68 & 9.20 & 0.96 & 67.80 \\
\hline 14 & 27.45 & 20.50 & 59.76 & 9.61 & 0.20 & 43.81 \\
\hline 15 & 36.98 & 78.79 & 355.70 & 13.41 & 2.94 & 131.01 \\
\hline 16 & 26.03 & 16.40 & 78.20 & 9.96 & 0.20 & 23.08 \\
\hline 17 & 25.90 & 403.75 & 425.04 & 16.60 & 3.31 & 55.05 \\
\hline 18 & 66.29 & 29.49 & 80.89 & 22.35 & 0.16 & 19.96 \\
\hline 19 & 35.98 & 21.95 & 94.32 & 7.05 & 0.27 & 26.30 \\
\hline 20 & 29.14 & 22.39 & 55.71 & 6.59 & 0.25 & 29.49 \\
\hline 21 & 33.23 & 24.71 & 62.46 & 5.83 & 0.35 & 33.48 \\
\hline 22 & 27.12 & 26.79 & 123.52 & 16.73 & 0.53 & 34.70 \\
\hline 23 & 13.14 & 12.84 & 75.45 & 8.85 & 0.37 & 37.38 \\
\hline 24 & 14.83 & 8.90 & 49.56 & 14.85 & 0.13 & 16.43 \\
\hline 25 & 22.56 & 17.16 & 50.26 & 3.81 & 0.28 & 30.45 \\
\hline 26 & 30.37 & 17.81 & 77.04 & 11.06 & 0.25 & 23.64 \\
\hline mean & 28.41 & 44.40 & 141.26 & 10.74 & 0.76 & 44.58 \\
\hline standard deviation & 1.21 & 9.07 & 1.55 & 4.52 & 114.05 & 3.28 \\
\hline
\end{tabular}


a)

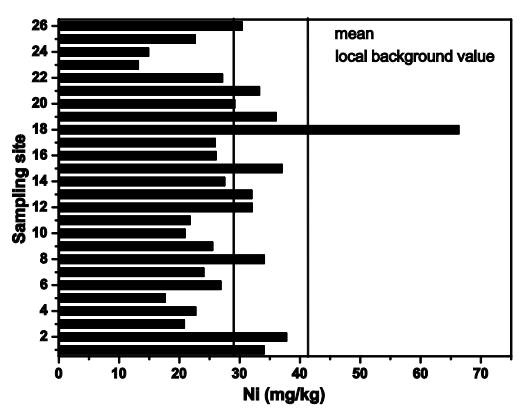

c)

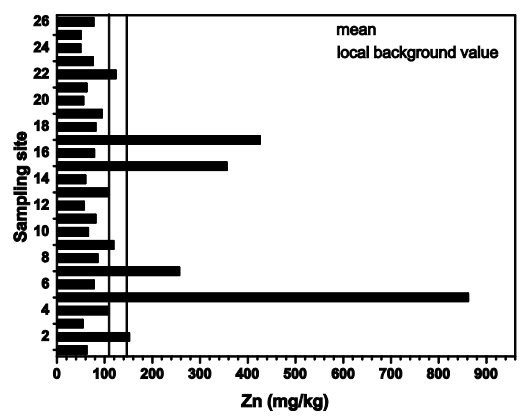

e)

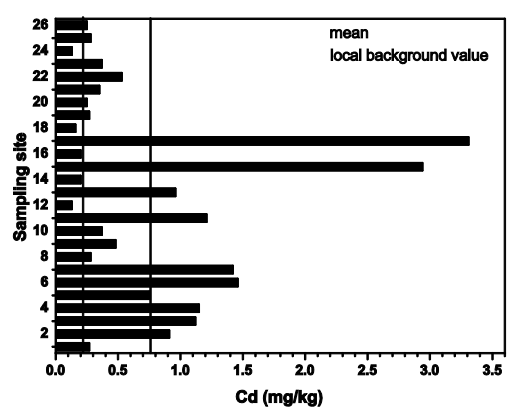

b)

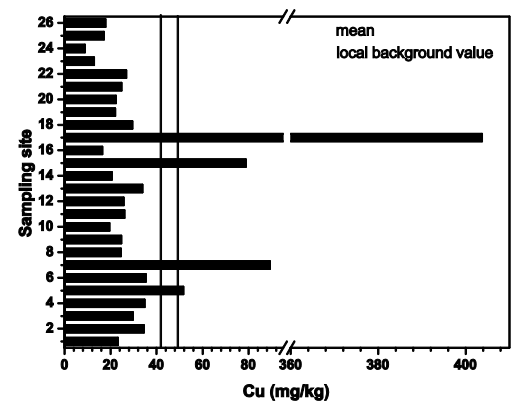

d)

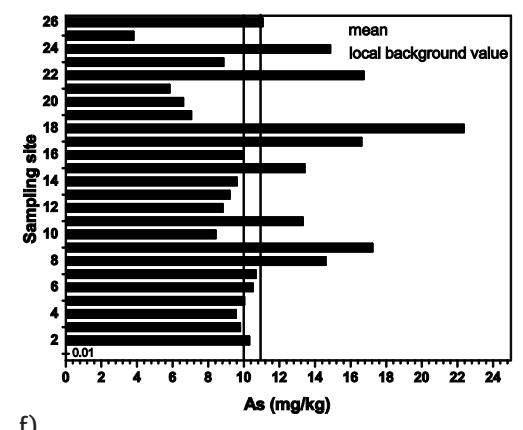

f)

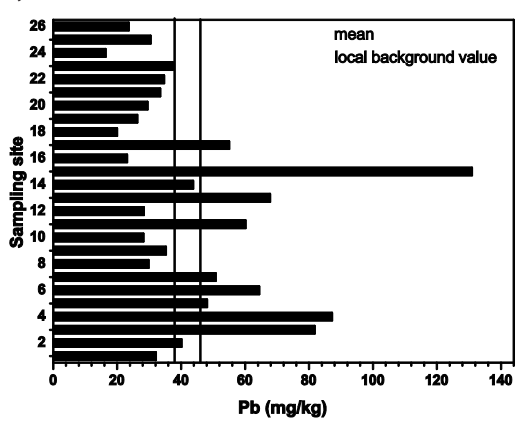

Figure 2: Concentrations histograms of $\mathrm{Ni}(\mathrm{a}), \mathrm{Cu}(\mathrm{b}), \mathrm{Zn}(\mathrm{c}), \mathrm{As}(\mathrm{d}), \mathrm{Cd}(\mathrm{e})$, and $\mathrm{Pb}(\mathrm{f})$ in surface sediments $\left(\mathrm{mg} \mathrm{kg}^{-1}\right)$

The variation coefficient was used to analyse the spatial distribution of heavy metal content in the surface sediments of the study areas. It can be calculated as follows:

$$
C V=S n / L n
$$

Where, for a certain heavy metal, CV is the variation coefficient, $\mathrm{Sn}$ is the standard deviation of the 26 sampling sites, and $\mathrm{Ln}$ is the mean value of the 26 sampling sites. 
Table 4 lists the variation coefficients of heavy metals in sediments. The variation coefficient decreased in the order of $\mathrm{Cd}>\mathrm{As}>\mathrm{Cu}>\mathrm{Pb}>\mathrm{Ni}>\mathrm{Zn}$. With the exception of $\mathrm{Cd}$, all heavy metals had small variation coefficients. This indicates the spatial distribution of each heavy metal was not uniform, mainly because the rivers suffer from different pollution sources.

Table 4: Variation Coefficients of Heavy Metals in Sediments

\begin{tabular}{llllll}
\hline $\mathrm{Ni}$ & $\mathrm{Cu}$ & $\mathrm{Zn}$ & $\mathrm{As}$ & $\mathrm{Cd}$ & $\mathrm{Pb}$ \\
\hline 0.04 & 0.20 & 0.01 & 0.42 & 150.07 & 0.07 \\
\hline
\end{tabular}

Fig. 3 presents the distribution of heavy metals in the sediments of the study areas, and RI (Table 5) was used to present the pollution level. Based on the above analysis, we divided this part of the river into three ecological function areas: upstream, midstream, and downstream. It is necessary to take steps to control heavy metals upstream (Cu, $\mathrm{Zn}, \mathrm{As}, \mathrm{Cd}$, and $\mathrm{Pb}$ ) and midstream (Ni, Cu, $\mathrm{Zn}, \mathrm{As}, \mathrm{Cd}$, and $\mathrm{Pb}$ ).

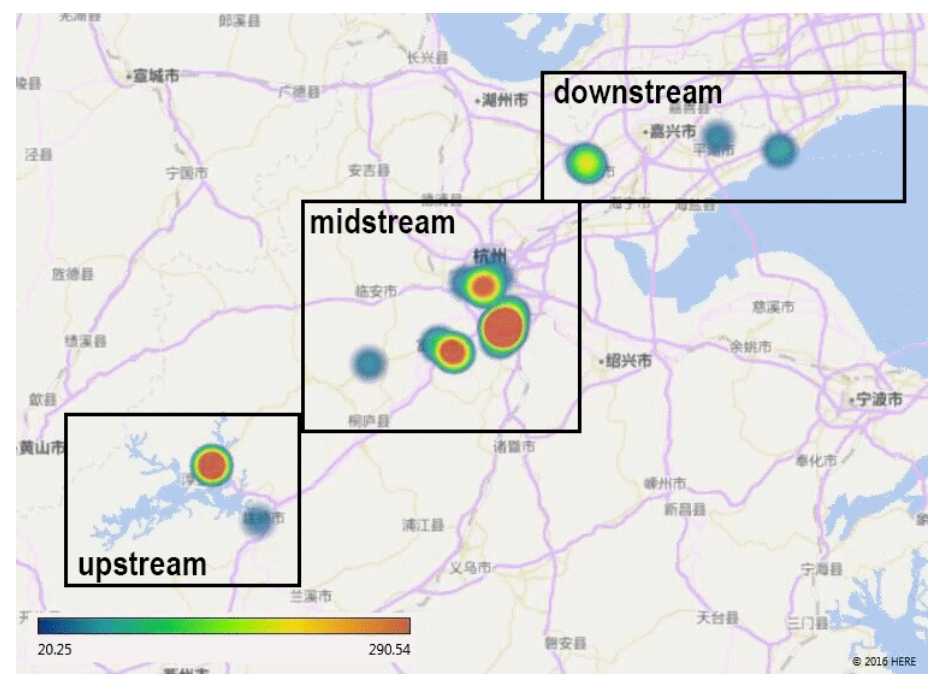

Figure 3: Distribution of heavy metals in sediment (RI)

\subsection{Potential Ecological Risk of Heavy Metals in Sediments}

Table 5 presents the result of the calculations of the single potential ecological risk index $\left(\mathrm{E}_{\mathrm{r}}^{\mathrm{i}}\right)$ and the integrated potential ecological risk index (RI) based on equations (2) and (3). It also lists the values of $\mathrm{E}_{\mathrm{r}}^{\mathrm{i}}$ and RI at each sampling site. The relation 
between $\mathrm{E}_{\mathrm{r}}^{\mathrm{i}}$, RI, and degree are listed below (Table 6), and the potential ecological risk assessments in the study areas are shown in Fig. 4.

Table 5: The Potential Ecological Risk Assessment for Heavy Metals in Sediments

\begin{tabular}{|c|c|c|c|c|c|c|c|}
\hline \multirow{2}{*}{$\begin{array}{l}\text { Sampling } \\
\text { sites }\end{array}$} & \multicolumn{6}{|c|}{$\mathrm{E}_{\mathrm{r}}^{\mathrm{i}}$} & \multirow[t]{2}{*}{$\mathbf{R} \mathbf{I}$} \\
\hline & $\mathrm{Ni}$ & $\mathrm{Cu}$ & $\mathrm{Zn}$ & As & Cd & $\mathrm{Pb}$ & \\
\hline 1 & 4.14 & 2.84 & 0.57 & 0.01 & 38.64 & 4.21 & 50.42 \\
\hline 2 & 4.59 & 4.23 & 1.38 & 10.30 & 130.25 & 5.25 & 156.00 \\
\hline 3 & 2.53 & 3.64 & 0.49 & 9.79 & 160.55 & 10.71 & 187.70 \\
\hline 4 & 2.76 & 4.27 & 0.96 & 9.55 & 164.41 & 11.41 & 193.36 \\
\hline 5 & 2.14 & 6.32 & 7.83 & 10.03 & 106.96 & 6.30 & 139.59 \\
\hline 6 & 3.26 & 4.33 & 0.71 & 10.51 & 208.86 & 8.44 & 236.11 \\
\hline 7 & 2.92 & 10.94 & 2.33 & 10.66 & 203.26 & 6.65 & 236.77 \\
\hline 8 & 4.14 & 3.00 & 0.78 & 14.59 & 40.45 & 3.90 & 66.86 \\
\hline 9 & 3.10 & 3.02 & 1.08 & 17.22 & 68.66 & 4.62 & 97.70 \\
\hline 10 & 2.54 & 2.40 & 0.60 & 8.42 & 53.51 & 3.69 & 71.16 \\
\hline 11 & 2.64 & 3.19 & 0.74 & 13.31 & 173.11 & 7.88 & 200.86 \\
\hline 12 & 3.90 & 3.15 & 0.52 & 8.81 & 18.79 & 3.71 & 38.88 \\
\hline 13 & 3.89 & 4.15 & 0.98 & 9.20 & 137.81 & 8.87 & 164.89 \\
\hline 14 & 3.34 & 2.51 & 0.54 & 9.61 & 29.12 & 5.73 & 50.86 \\
\hline 15 & 4.50 & 9.66 & 3.23 & 13.41 & 420.39 & 17.15 & 468.34 \\
\hline 16 & 3.17 & 2.01 & 0.71 & 9.96 & 28.03 & 3.02 & 46.91 \\
\hline 17 & 3.15 & 49.48 & 3.86 & 16.60 & 472.20 & 7.21 & 552.51 \\
\hline 18 & 8.06 & 3.61 & 0.74 & 22.35 & 22.90 & 2.61 & 60.28 \\
\hline 19 & 4.38 & 2.69 & 0.86 & 7.05 & 38.30 & 3.44 & 56.71 \\
\hline 20 & 3.55 & 2.74 & 0.51 & 6.59 & 35.59 & 3.86 & 52.83 \\
\hline 21 & 4.04 & 3.03 & 0.57 & 5.83 & 50.43 & 4.38 & 68.28 \\
\hline 22 & 3.30 & 3.28 & 1.12 & 16.73 & 75.68 & 4.54 & 104.66 \\
\hline 23 & 1.60 & 1.57 & 0.69 & 8.85 & 53.15 & 4.89 & 70.76 \\
\hline 24 & 1.80 & 1.09 & 0.45 & 14.85 & 18.17 & 2.15 & 38.51 \\
\hline 25 & 2.74 & 2.10 & 0.46 & 3.81 & 40.08 & 3.99 & 53.18 \\
\hline 26 & 3.69 & 2.18 & 0.70 & 11.06 & 35.05 & 3.09 & 55.78 \\
\hline
\end{tabular}

Table 6: The Relation Between $\mathrm{E}_{\mathrm{r}}^{\mathrm{i}}$, RI, and Degree [16]

\begin{tabular}{llll}
\hline $\mathrm{E}_{r}^{\mathrm{i}}$ and degree & & $\mathrm{RI}$ and degree & \\
\hline$E_{r}^{i}<40$ & low & $\mathrm{RI}<150$ & low \\
$40 \leq E_{r}^{i}<80$ & moderate & $150 \leq \mathrm{RI}<300$ & moderate \\
$80 \leq E_{r}^{i}<160$ & higher & $300 \leq \mathrm{RI}<600$ & severe \\
$160 \leq E_{r}^{i}<320$ & high & $\mathrm{Rl}>600$ & serious \\
$E_{r}^{i} \geq 320$ & serious & & \\
\hline
\end{tabular}




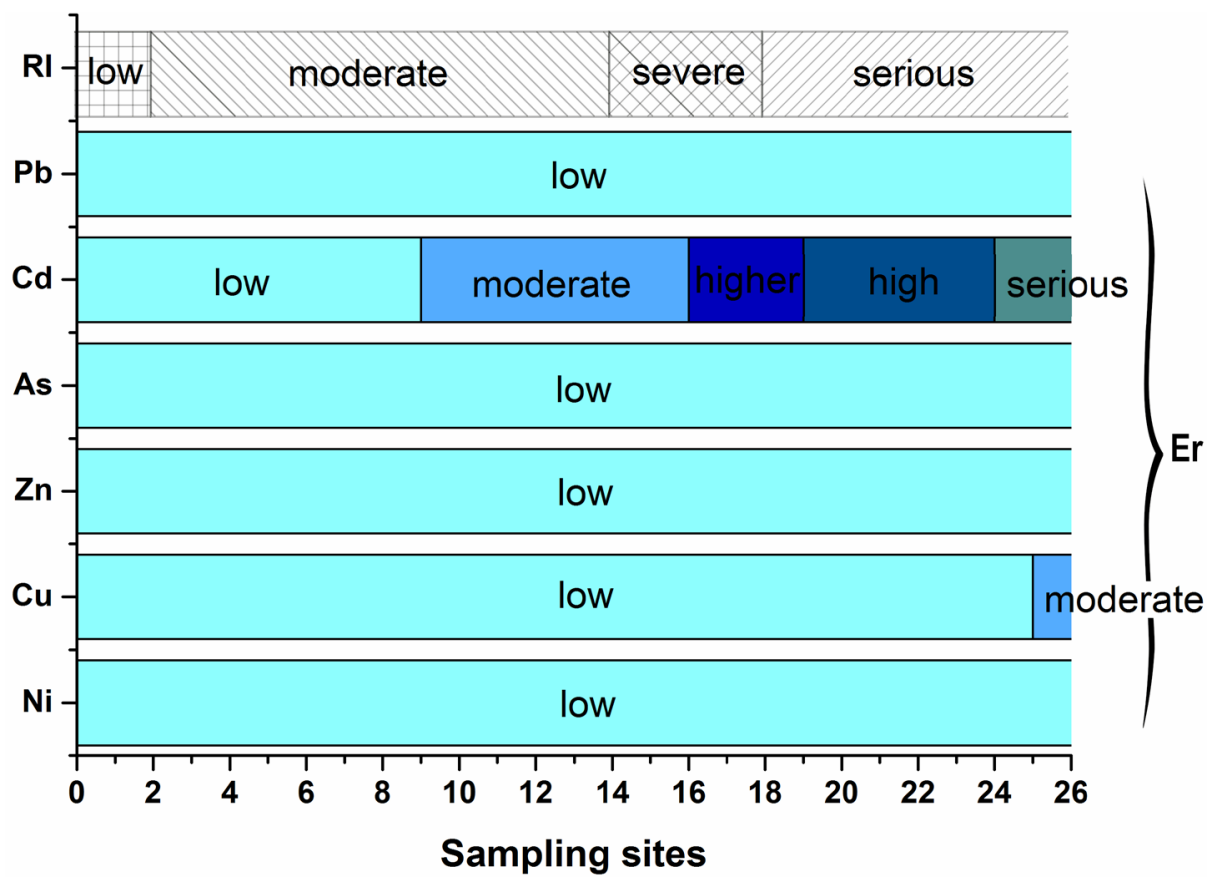

Figure 4: The potential ecological risk assessment for heavy metals in the study areas

Most potential ecological risk indexes ( $\mathrm{E}_{\mathrm{r}}^{\mathrm{i}}$ ) for Cd exceeded 40 (Fig. 3), and nearly half of them exceeded 80 and fell into the higher risk category. The $\mathrm{E}_{\mathrm{r}}^{\mathrm{i}}$ values for $\mathrm{Ni}, \mathrm{Zn}$, $\mathrm{As}$, and $\mathrm{Pb}$ were less than 40, and indicated low risk. The $\mathrm{E}_{\mathrm{r}}^{\mathrm{i}}$ of $\mathrm{Cu}$ ranged from 1 to 10 (except one in 49.98), which indicated low risk. The potential ecological risk values $\left(\mathrm{E}_{\mathrm{r}}^{\mathrm{i}}\right)$ decreased in the order of $\mathrm{Cd}>\mathrm{As}>\mathrm{Pb}>\mathrm{Cu}>\mathrm{Ni}>\mathrm{Zn}$. RI values ranges from 30 to 600 , and around half of them were higher than 150, which indicated that the integrated potential ecological risk at nearly 13 sampling sites was moderate. The average contribution proportions of $\mathrm{E}_{\mathrm{r}}^{\mathrm{i}}$ of $\mathrm{Ni}, \mathrm{Cu}, \mathrm{Zn}, \mathrm{As}, \mathrm{Cd}$, and $\mathrm{Pb}$ to RI were $2.55 \%, 4.02 \%$, $0.95 \%, 7.93 \%, 80.24 \%$, and $4.31 \%$, respectively. Of these, Cd contributed the most. These results show that $\mathrm{Cd}$ is the element with the potential to cause most ecological damage.

\section{Conclusions}

1. According to heavy metal distribution in sediments, we divided this part of the river into three ecological function areas: upstream, midstream, and downstream. It is necessary to take steps to control heavy metals in the upstream $(\mathrm{Cu}, \mathrm{Zn}, \mathrm{As}$, $\mathrm{Cd}$, and $\mathrm{Pb}$ ) and midstream ( $\mathrm{Ni}, \mathrm{Cu}, \mathrm{Zn}, \mathrm{As}, \mathrm{Cd}$, and $\mathrm{Pb}$ ) portions of the Qiantang River, China. 
2. Comparison shows that pollution from $\mathrm{Cd}$ is more severe than the pollution from other metals, with an average concentration 3.62 times higher than the background levels. The risk from $\mathrm{Cu}$ is slight/medium, while the risks from Ni, $\mathrm{Zn}$ is low.

Acknowledgment: This study was supported by Natural Science Foundation of Zhejiang Province (No. LY13E090005).

\section{References}

[1] Vallee B.L., Ulmer D.D., Biochemical Effects of Mercury, Cadmium, and Lead, Annual Review of Biochemistry, 1972, 41, 91-128.

[2] Wang S., Jia Y., Wang S., Xin W., He W., Zhao Z., Liu B., Fractionation of heavy metals in shallow marine sediments from Jinzhou Bay, China, Journal of Environmental Sciences, 2010, 22, 23-31.

[3] Ajmal M., Raziuddin, Khan A.U., Heavy metals in water, sediments, fish and plants of river Hindon, U.P., India, Hydrobiologia, 1987, 148 151-157.

[4] Papagiannis I., Kagalou I., Leonardos J., Petridis D., Kalfakakou V.,, Copper and zinc in four freshwater fish species from Lake Pamvotis (Greece), Environment International, 2004, 30, 357-362.

[5] Ebrahimpour M., Mushrifah I., Seasonal variation of cadmium, copper, and lead concentrations in fish from a freshwater lake., Biological Trace Element Research, 2010, 138, 190-201.

[6] Hadi H.E., Assessment of Heavy Metals Soil Contamination in the Abandoned Pb-mine of Zaida (Morocco), European Journal of Scientific Research, 2015, 129, 167-178.

[7] Fu W., Meng F., Wang Z., Wang Q., Li Y., Zhou Y., Cheng F., Heavy metals in the intertidal sediments and two marine bivalves along the Beibu Bay: Contamination status and bioaccumulation, Acta Scientiae Circumstantiae, 2013, 33, 1401-1409.

[8] Bibi M.H., Ahmed F., Ishiga H., Assessment of metal concentrations in lake sediments of southwest Japan based on sediment quality guidelines, Environmental Geology, 2007, 52, 625-639.

[9] Yu L., Zhi-ming Y., Xiu-xian S., Application of Principal Component Analysis (PCA)for the Estimation of Source of Heavy Metal Contamination in Marine Sediments, ENVIRONMENTAL SCIENCE, 2006, 27, 137-141.

[10] van den Berg GA., Meijers GG., van der Heijdt LM., Zwolsman JJ., Dredging-related mobilisation of trace metals: A case study in The Netherlands, Water Research,2001, 35, 1979-1986.

[11] Weber P., Behr E.R., Knorr C.D.L., Vendruscolo D.S., Flores E.M.M., Ssler V.L., Baldisserotto B., Metals in the water, sediment, and tissues of two fish species from different trophic levels in a subtropical Brazilian river, Microchemical Journal, 2013, 106, 61-66.

[12] Hakanson L., An ecological risk index for aquatic pollution. A sedimentological approach, Water Research, 1980, 14, 975-1001.

[13] Nouri M., Haddioui A.E.M., Assessment of metals contamination and ecological risk in ait Ammar abandoned iron mine soil, Morocco, Ekologia, 2016, 35, 32-49.

[14] Wang F., Huang Y., Wang X., Gao Z., Faxin Y.U., Feng X.U., Bao Q., Ying H.U., Qiao M., Jin S., Ecological risk assessment of heavy metals in surrounding soils of tungsten ores: Comparison of different evaluation methods, Environmental Chemistry, 2015.

[15] Solgi E., Ahmadi F.Y., Ecological risk assessment of cadmium and lead in urban and forest park soils in Asadabad City, Iran., Journal of School of Public Health \& Institute of Public Health Research,2015. 
[16] Hakanson L., An ecological risk index for aquatic pollution control.a sedimentological approach, Water Research, 1980, 14, 975-1001.

[17] Wang Q.H., Dong Y.X., Zhou G.H., Zheng W., Soil Geochemical Baseline and Environmental Background Values of Agricultural Regions in Zhejiang Province., Journal of Ecology \& Rural Environment, 2007, 23, 81-88. 